\title{
Customer responses to CSR in the Pakistani banking industry
}

\section{Structured abstract}

Purpose - The purpose of the paper is twofold: (1) to empirically analyse how customer CSR perceptions impact on the PSQ-loyalty relationship in the banking industry of Pakistan and (2) to evaluate the mediating role of customer trust in that model.

Design/methodology/approach - Based on a field survey of 408 customers of five different banks of Pakistan, the hypothesized model is tested through partial least squares based structural equation modelling.

Findings - The findings demonstrate that banking customers in Pakistan recognize CSR as a multidimensional construct that serves as a direct determinant of perceived service quality, trust, repurchase and word of mouth intentions. Perceived service quality also influences customer trust directly and positively and trust has a direct and positive impact on repurchase and word of mouth intentions. On the contrary, perceived service quality does not influence repurchase and word of mouth intentions directly. Its effect is mediated by customer trust.

Practical implications - Contrary to the previous mixed findings reported in the literature, this research confirms the explicit contribution of CSR towards customer perceptions and intentions in the context of the banking industry. The findings suggest that banking companies should take great care over preparing their CSR initiatives and include them in their marketing plans in order to improve customer loyalty intentions. In this way, CSR can enhance perceived service quality and customer trust, which are two key constructs in the loyalty model proposed in this paper.

Originality/value - The originality of the paper lies in the context in which the research was developed. The banking industry of Pakistan had not previously been extensively researched. The proposal for a comprehensive model that evaluates the role of customer trust is another key contribution of the paper. Previous research has not extensively studied the role of trust in loyalty models that evaluate CSR perceptions along with perceived service quality.

Keywords - Corporate social responsibility; Perceived service quality; Trust, Word of mouth; Repurchase; Loyalty; Retail banking; Developing economy; Pakistan

Article classification - Research Paper 


\section{Introduction}

Nowadays, due to the numerous benefits that are associated with corporate social responsibility (hereafter CSR), firms are encouraged to spend millions on CSR activities (Becker-Olsen et al., 2006; Pirsch et al., 2007). Considering CSR as an investment decision (McWilliams and Siegel, 2001), the concept has gained increased attention and it is frequently used by companies as a specific marketing tool to garner favourable attitudes about long term relationships with stakeholders (Maignan and Ferrell, 2001; Becker-Olsen et al., 2006; García de los Salmones et al., 2009). Thus, CSR has begun to be considered as an important part of the corporate marketing mix (Pirsch et al., 2007). Although CSR has been the subject of considerable interest in exploring its multipurpose benefits, most of the studies discuss the effect of CSR management on a firm's reputation and image (Eberle et al., 2013). However, there has been only limited research into the effect of CSR on customer perceptions and intentions (Pérez et al., 2013a). In this regard, it is important to state that firms consider customers as being among of their most important stakeholders and, that therefore, the academic study of customer intentions should be a priority in business research (Sen and Bhattacharya, 2001).

For example, there has been very little research into how customer CSR perceptions affect the relationship between perceived service quality (hereafter PSQ) and loyalty (García de los Salmones et al., 2005). Scholars acknowledge PSQ as a traditional performance criterion to evaluate a firm's overall competitive position and financial success (Zeithaml et al., 1996; Lewis and Soureli, 2006) and confirm its relevance in generating customer satisfaction, commitment and loyalty intentions. However, due to the growing competition and the limitations involved in achieving differentiation through PSQ, companies are now interested in knowing whether there is an opportunity for them to achieve customer loyalty, not only through service expertise but also through CSR activities (García de los Salmones et al., 2005).

The purpose of the authors here is to fill in previous gaps in the literature by empirically analysing how customer CSR perceptions impact on the PSQ-loyalty relationship in the banking industry of a developing economy such as Pakistan. In order to do this, the authors identify three contributions of the study to the academic literature.

Firstly, previous scholars who have studied the role of CSR perceptions in the PSQ-loyalty relationship have reported mixed findings (García de los Salmones et al., 2005; He and Li, 2011; Arkan and Güner, 2013). For instance, García de los Salmones et al. (2005) report a positive link between CSR perceptions and PSQ. However, their findings do not support the existence of a positive relationship between CSR perceptions and loyalty intentions. On the contrary, $\mathrm{He}$ and $\mathrm{Li}$ (2011) report weak interaction effects between CSR perceptions and PSQ and demonstrate that customers are more loyal when companies care for both CSR and PSQ. Thus, it seems that the role of CSR perceptions in the PSQ-loyalty link is still unclear and new research is needed in this regard (Walsh and Bartikowski, 2013).

Secondly, it has been observed that there are relevant variables that have not been focused in the study of the effect of CSR perceptions on loyalty intentions. Most significantly, scholars have demonstrated that trust is a central variable in building long-term relationships with customers (Morgan and Hunt, 1994). More specifically, in the case of banking industry, banks manage customers' wealth and due to this fact, trust is considered an especially important factor in the customer-bank relationship (Lewis and Soureli, 2006). Nonetheless, researchers have succinctly 
studied the link of trust to CSR perceptions and thus the role of this variable in CSR-PSQ-loyalty models has been understudied in previous literature of the banking industry. Taking these previous ideas into account, it is noticeable that significant gaps remain in the literature on the CSR-PSQ-loyalty link. Specifically, there is no research available so far that clearly identifies the impact of perceptions of CSR on PSQ, trust and loyalty intentions such as repurchase and word of mouth (hereafter WOM) intentions in the context of real customers of banking institutions in a developing country.

Thirdly, most of the previous literature has been developed in the context of developed economies (García de los Salmones et al., 2005; He and Li, 2011; Pérez et al., 2013a). Nonetheless, few papers have analysed customer responses to CSR perceptions in emerging countries and the few that have dealt with the topic have limited their contribution to the study of customer CSR expectations instead of customer perceptions of real CSR activities implemented by banking companies (McDonald and Rundle-Thiele, 2008; Mandhachitara and Poolthong, 2011; McDonald and Lai, 2011). The authors chose Pakistan as the research context of this study because it is a clear example of a country that has been understudied in comparison to the European and North American contexts. Pakistan is currently the sixth most populated country in the world, with over 180 million inhabitants, but the forty-third largest country in terms of its GDP. Studying emerging markets is worthwhile as they comprise of over two-thirds of the world's population and one-fifth of its GDP. Further, the banking industry of Pakistan has been chosen that has matured to such a significant level that justifies its consideration for this research. As of December, 2013, according to the State Bank of Pakistan (SBP), the banking industry of Pakistan comprises of forty five banks, including seven foreign banks and consists of around 10,000 branches and 8000 ATMs. The growing banking industry of Pakistan plays a vital role in the overall growth of the economy with a total deposits of over seventy billion, investments of over forty billion and advances of over six billion US dollars approximately (SBP, 2013). The presence of a large number of banks reflects tough competition in this industry. Scholars have also reported that Pakistani banking industry undergoes intense competition (Mohsan et al., 2011). Due to this reason, many banks in this industry are expanding their boundaries in terms of Islamic, mobile and online banking. According to previous scholars, when firms face fierce competition in a service industry, in addition to improve their service performance, firms also seek additional ways of marketing in order to garner favourable customer attitudes (Poolthong and Mandhachitara, 2009). In this regard, engagement in CSR activities can serve as a strategic marketing tool for a firm's competitive advantage (McWilliams and Siegel, 2001, Porter and Kramer, 2006). Therefore, the present research attempts to address how CSR impact on the customer attitudes of those banks that actively involved in doing and marketing of their CSR activities. In this regard, it is noticeable that only a few studies report the existence of weak interaction effects between PSQ and CSR (He and Li, 2011) or experimentally reveal that CSR can substitute service performance (quality) of the firm in particular conditions (Berens et al., 2007). Consistent with the broader research stream (García de los Salmones et al., 2005; Matute et al., 2011; Pérez et al., 2013a), the authors do not intend that CSR can be a substitute for or has interaction/moderating effects with/on core business activities of banks. Nonetheless, the main purpose of the research is to investigate the direct effect of CSR perceptions on customer attitudes namely service quality, trust and repurchase and WOM intentions. In addition to this, the authors also evaluate the core business model of service quality-loyalty intentions by incorporating the mediating role of trust. 
The remainder of the paper is structured as follows. In the next section, the authors review the concept of CSR and its effect on customer intentions. They also propose their conceptual model and hypotheses. Furthermore, the authors describe the method applied to the study, including a revision of the data collection, the sampling procedure and the measurement scales developed for the research. The authors present and discuss the findings of the research. Finally, the paper concludes with a summary of the theoretical and practical contributions of the research along with the limitations and future lines of research derived from the study.

\section{Literature review and hypothesis development}

\subsection{CSR conceptualization}

Many CSR definitions are found in the literature (Pérez et al., 2013b). In many academic papers CSR is defined as the combination of the economic, legal, ethical and philanthropic responsibilities that a firm has towards society (Carroll, 1979; García de los Salmones et al., 2005; Pérez et al., 2013a). Obligations within the economic domain include, for example, profit maximization for shareholders, obtaining the best value for money, the establishment of a strong competitive position and maintaining a high level of operating efficiency (Pérez et al., 2013b). The legal category is defined by the rule of law (Carroll, 1979). The ethical dimension covers corporate activities that are expected by society but not codified in legal codes (Schwartz and Carroll, 2003). The philanthropic dimension poses a set of voluntary actions that go beyond the purely ethical, such as donations to charitable causes, active participation in environmental conservation, or sponsorship of cultural activities (Carroll, 1979). From a stakeholder's perspective CSR is viewed as a construct that encompasses ethical, legal, economic and philanthropic activities relating to the obligations of firms towards their stakeholders (Freeman, 1984; Pérez et al., 2013b). In this regard, the stakeholder theory (Freeman, 1984) suggests a dimensioning of CSR according to the main target groups of a firm. According to this proposal, CSR activities should preferably be classified as the domain of those stakeholders who receive the most benefit from those activities. Applying this reasoning, scholars have identified several CSR dimensions such as customers, employees, shareholders, society and the environment (Pérez et al., 2013b).

Nonetheless, in this study the authors only consider three of the dimensions of the CSR construct proposed by Carroll (1979) (i.e., ethical CSR, legal CSR and philanthropic CSR). This CSR construct has been applied in previous CSR-PSQ-loyalty studies (García de los Salmones et al., 2005; Pérez et al., 2013a). The authors deliberately exclude the economic dimension from the analysis because its recognition by customers and its influence on customer intentions have been questioned by scholars (Aupperle et al., 1985; Maignan and Ferrell, 2001; García de los Salmones et al., 2005). Aupperle et al. (1985) conclude that CSR perceptions can be measured in terms of the importance of three non-economic components (law, ethics and philanthropy). They observe that the economic dimension is inversely correlated with these components. Thus, customers do not consider economic responsibilities as part of CSR. Maignan and Ferrell (2001) argue that customers frequently exclude the economic dimension from the CSR construct. Finally, García de los Salmones et al. (2005) empirically demonstrate that the economic behaviour of companies is perceived as an independent factor in corporate behaviour by customers. 


\subsection{CSR and customer behaviour}

CSR has become a concept of much interest because of its multiple benefits for firms (BeckerOlsen et al., 2006). Some of these benefits include the improvement of employee motivation and commitment, the generation of competitive advantages over competitors, sales growth, reputation and brand image (Sen and Bhattacharya, 2001; Eberle et al., 2013). Based on this idea, firms and scholars have started to think of CSR as a marketing tool (Brown and Dacin, 1997; García de los Salmones et al., 2005, 2009; Porter and Kramer, 2006). For example, through experimental research Brown and Dacin (1997) reveal that a firm's product expertise is not the only factor that contributes to positive customer evaluations. On the contrary, CSR activities can also be used for this purpose. Similarly, García de los Salmones et al. (2009) also argue that customers are attracted towards their firms' CSR activities and that positive perceptions create better evaluations of service performance.

Indeed, firms nowadays not only try to become more socially responsible, but they also make their CSR activities more visible to their customers by means of increased media coverage (Pirsch et al., 2007). For example, in this digital era socially responsible firms are keen to communicate their CSR activities through their websites and interactive online media (Eberle et al., 2013). Additionally, new profitable strategies continue to emerge due to the fact that these firms invest in CSR activities as part of their marketing management approach (Matute et al., 2011). Therefore, the role of CSR perceptions is nowadays closely associated with service quality performance in long term relationships (García de los Salmones et al., 2005) and restoration of positive customer attitudes after service failures and recovery (Choi and La, 2013). Most importantly, it is also emerging as a crucial factor in broadening the base of loyal customers (García de los Salmones et al., 2009; Lee et al., 2012; Pérez et al., 2013a).

Despite most of the studies published in this field, the positive effect of CSR perceptions on customer responses perhaps needs further research, especially if we consider the impact of CSR perceptions on PSQ and loyalty intentions. Recently, Walsh and Bartikowski (2013) report inconsistent findings in a cross cultural setting. They reveal a positive link between CSR and loyalty behaviour in their German customer sample while the US customer sample does not show a positive correlation between CSR perceptions and loyalty intentions. However, these scholars do not reveal any link between CSR perceptions and PSQ in either of their samples. These findings contradict the ideas previously defended by García de los Salmones et al. (2005), who report a positive link between CSR perceptions and PSQ but not between CSR perceptions and loyalty intentions.

In this paper, the authors extend García de los Salmones et al.'s (2005) CSR-PSQ-loyalty model to deepen the research into the effects of CSR perceptions on PSQ and loyalty. For that purpose, the authors evaluate the role of another variable, customer trust, which has not been focused by previous scholars who are aligned with this stream of research. Trust is a central concept in building long-term relationships with customers (Morgan and Hunt, 1994). Nonetheless, its link to CSR perceptions has not been deeply analysed in the previous literature. Trust is especially important in a high risk and high involvement relationship, such as in the case of the banking industry, where customers perceive it as a determining factor in whether they continue or discontinue their relationship with their bank (Lewis and Soureli, 2006). The strategic significance of trust and its relevance as a central variable in customer intentions makes its study 
an essential step forward in the knowledge and understanding of the customer intentions that derive from both, service quality and CSR perceptions.

Figure 1 shows the conceptual framework that is tested in this paper.

\section{Insert Figure 1 here}

\section{CSR perceptions and $P S Q$}

Brown and Dacin (1997) argue that firms can position themselves in the marketplace through their product expertise and/or through their CSR activities. Product expertise is a frequently denominated service quality in service literature (García de los Salmones et al., 2005; He and Li, 2011; Walsh and Bartikowski, 2013). PSQ is viewed as a customer judgment about a service provider's overall excellence (Parasuraman et al., 1988).

Previous scholars have also confirmed that a positive link exists between customer CSR perceptions and PSQ. For example, Poolthong and Mandhachitara (2009) report that customers expect their firms to be socially responsible and that these CSR expectations are positively related to PSQ. When evaluating customer CSR perceptions, García de los Salmones et al. (2005) report that CSR perceptions are significant direct determinants of PSQ in Spanish telecommunication customers. Also, Sureshchandar et al. (2001) argue that a firm's ethical responsibility is closely associated with PSQ. Sureshchandar et al. (2002) even posit that a firm's ethical responsibility should be assumed as a component of PSQ in the banking industry. García de los Salmones et al. (2009) reveal a positive link between the ethical dimension of CSR perceptions and the commercial performance of banks. More recently, Choi and La (2013) examine ethical-legal responsibility in the context of service failure and recovery and report that CSR perceptions play an important role in restoring customer loyalty, while Chomvilailuk and Butcher (2013) reveal a positive relation between banks' philanthropic CSR and customers' attitudes to those banks.

All in all, there is evidence that CSR activities and PSQ are closely related. Thus, the first research hypothesis can be proposed:

\section{H1: CSR perceptions directly and positively affect PSQ}

\section{CSR perceptions and trust}

It is noteworthy that corporate scandals, unethical behaviour and manipulative CSR campaigns cause customers scepticism to increase (Becker-Olsen et al., 2006; Vlachos et al., 2009). Customers demand ethically justifiable behaviour from their firms and when they perceive that this is occurring, it creates trust in them. Morgan and Hunt (1994) define trust as the existence of a relationship where one exchange partner believes in the other's reliability and integrity.

A firm's CSR activities engender its image of honesty, integrity, credibility and high responsiveness towards customer concerns (Sirdeshmukh et al., 2002). Maignan and Ferrell (2001) argue that a firm's CSR activities can be a good source of customer trust and reduction of scepticism. Past studies have positioned trust as a central construct in long term relationships (Morgan and Hunt 1994). For example, Swaen and Chumpitaz (2008) study cosmetics and sportswear customers and report that CSR perceptions positively impact on customer trust. These 
scholars argue that CSR perceptions and trust are significant variables in the cultivation of long term affiliations between customers and firms. Moreover, García de los Salmones et al. (2009) identify a direct relationship between a firm's ethical responsibility and customer trust in retail service markets. Similarly, Choi and La (2013) state that a firm's ethical-legal responsibility positively affects customer trust in service contexts.

Based on the theoretical and empirical arguments stated above, the following hypothesis is proposed:

\section{H2: CSR perceptions directly and positively affect customer trust}

\section{CSR perceptions and loyalty intentions}

Loyalty refers to the strength of the relationship between a customer's relative attitude (i.e., WOM) and his/her repeated patronage (i.e., repurchase) (Dick and Basu, 1994). The segregation of loyalty into repurchase and WOM intentions is important due to the fact that customer repurchase trends can be derived more from their routine patterns and less from their real positive commitment towards firms' products or services. If this is the case, this type of loyalty, which is referred to as spurious loyalty, can be very fragile if new competitors with more appealing offers enter the market (Dick and Basu, 1994). On the contrary, WOM intentions are considered to be superior measurements of loyalty because they lead to real loyalty; , a loyalty that is not dependent on routine patterns or the lack of alternatives but that depends directly on the commitment of customer to firms (Bloemer et al., 1999). Thus, WOM intentions are key indicators of positive customer attitudes towards firms' products and services (Cronin and Taylor, 1992). Based on these ideas, in this paper the authors study the two components of loyalty intentions such as repurchase and WOM intentions independently and therefore the impact of CSR perceptions, PSQ and trust is hypothesized on both constructs.

According to previous experimental studies, customers have positive loyalty intentions when they know about their firms' CSR activities (Brown and Dacin, 1997; Sen and Bhattacharya, 2001). In an exploratory study, Pirsch et al. (2007) describe a positive relationship between a firm's CSR activities and customer repurchase intentions. In an empirical study of telecommunication customers, He and Li (2011) demonstrate that CSR perceptions are positively related to brand loyalty through customer satisfaction and brand identification. Similarly, in the banking industry CSR perceptions are found to have indirect links with loyalty through satisfaction, commitment, price fairness and identification with the company (Matute et al., 2011; Pérez et al., 2013a). Nonetheless, few recent marketing studies have empirically evaluated whether CSR perceptions can also have a direct positive effect on customer loyalty or not (Lee et al., 2011, 2012; Choi and La, 2013). This idea still needs further investigation to establish if CSR perceptions are direct antecedents of loyalty in the banking industry. Similarly, two new research hypotheses propose that:

\section{H3a: CSR perceptions directly and positively affect repurchase intentions}

\section{H3b: CSR perceptions directly and positively affect WOM intentions}

$P S Q$, trust and loyalty intentions 
Customer loyalty is the primary criteria used to assess the effectiveness of customer retention strategies and this assessment cannot be achieved without considering the important determinants of loyalty (Lewis and Soureli, 2006). In service markets, scholars reveal that service quality is the primary factor in achieving customer loyalty (Parasuraman et al., 1988). Nonetheless, there are numerous other factors found in the literature that play significant role in order to achieve loyal customers. For example, Kantsperger and Kunz (2010) suggest that trust also serves as a key driver of customer retention strategies in retail service markets. Sirdeshmukh et al. (2002) demonstrate the link between trust, perceived value and loyalty. Prior research has also established the significant role of trust as a mediating variable between PSQ and loyalty. For instance, Chiou and Droge (2006) conclude that trust is a mediating variable between PSQ and loyalty. Lewis and Soureli (2006) reveal that PSQ and trust are the main antecedents of loyalty intentions in the banking industry. Similarly, Qureshi et al. (2009) evaluate the mediating role of trust in the context of online banking. Taking the previous literature into account, it is evident that the effect of PSQ on customer repurchase and WOM intentions among banking customers is mediated by trust. Therefore, three new hypotheses can be proposed:

\section{H4: PSQ directly and positively affects customer trust}

\section{H5a: Customer trust directly and positively affects repurchase intentions}

\section{H5b: Customer trust directly and positively affects WOM intentions}

As discussed earlier, this research also attempts to confirm whether trust plays as a mediating variable in the relationship of PSQ-loyalty intentions, therefore, direct paths between PSQ and repurchase and WOM intentions are also hypothesized with the help of the findings revealed in the literature. In this regard, the PSQ-loyalty direct link has also been reported by several scholars (Zeithaml et al., 1996; Bloemer et al. 1999). These researchers have argued that PSQ is a direct determinant of loyalty, without requiring any mediating variable. Bloemer et al. (1999) study the direct PSQ effect on loyalty intentions, such as repurchase and WOM intentions, along with the impact of price sensitivity and intentions to complain. Similarly, Cronin and Taylor (1992) confirm PSQ's direct relationship with WOM intentions. Thus, two hypotheses can be proposed:

\section{H6a: PSQ directly and positively affects repurchase intentions}

\section{H6b: $P S Q$ directly and positively affects WOM intentions}

Finally, the authors of this research formulate their last hypothesis by postulating a link between customer repurchase and WOM intentions. It may also be worthwhile to know whether customers who intend to continue relationships with their respective banks will also intend to recommend their banks or not to others. Customers with positive repurchase intentions are more likely to recommend their banks to other people (i.e., their family and friends). However, this can be vice versa if customers have to face constraints like high costs of switching, attractiveness of alternate service provider etc. (Dick and Basu, 1994). Some scholars have evaluated the link between customer repurchase and WOM intentions (Nadiri et al. 2008; Vanniarajan, 2011). With regard to this, the last hypothesis of this paper can be proposed:

\section{H7: Repurchase intentions directly and positively affect WOM intentions}




\section{Research methodology}

\subsection{Data collection and sampling procedure}

To test the research hypotheses, the authors applied a field survey approach (i.e., directly asking real customers about their bank's CSR and PSQ in a real context). A number of banking customers were randomly approached as they exited a banking branch after the completion of a transaction. A quick post transaction mode helped us to get around the problem of low CSR awareness as it was considered that the customer's latest visit to their branch and their fresh transaction experience might be helpful in helping them recall their banks' CSR activities. Data was collected in Islamabad, the capital of Pakistan, and Rawalpindi, an adjacent city to the capital of the country. These cities have a total population of six million inhabitants and serve as economic and educational hubs for the country. The data was collected between December 2012 and February 2013.

A sampling restriction was set in order to collect at least 75 responses from each of five different banks to ensure the adequate representation of customers in the final data analysis. The authors chose five banking companies that were actively involved in CSR activities (García de los Salmones et al., 2005). For this purpose, an exploratory study was conducted prior to the field survey. According to the State Bank of Pakistan, twenty nine banks were offering retail banking services in the country in 2012-2013. Non-generalised banks like Islamic banks, micro-finance, development finance and agricultural banks were not included in the study due to their specific banking characteristics and target audience. Out of twenty nine retail banks, five were in the public sector, while seventeen were domestic and the remaining seven were foreign-owned. To establish which banks were involved in CSR, extensive preliminary research was conducted into these twenty nine banks. Considerable efforts were made to learn about their CSR activities and the ways in which they communicated these activities to their customers. Three banking experts and two faculty members from the marketing field participated during the exploratory stage. The official websites of the banks, their press releases about CSR events in newspapers and electronic media were explored. Based on this research, the authors consider that a bank would be treated as being eligible for the study only if: (1) it had a separate webpage for its CSR activities on its official website, (2) it transmitted CSR-related press releases/news in electronic and print media and (3) it reported its CSR activities in its annual reports by clearly indicating the amount of CSR investment. Only five banks met these criteria and these were included in the study. Three of them were domestic banks and two were foreign-owned.

A total of 408 valid responses were collected from customers of these five banks. 52 percent of the respondents were male, while 48 percent were female. 52 percent of the respondents were 20-40 years old, while 41 percent were $40-60$ years old. 43 percent of the respondents had a Bachelor's degree and 32 percent had a Master's degree. 61 percent of the respondents were office employees in the public or private sector, while 18 percent were entrepreneurs.

\subsection{Measurement scales}

Multi-item constructs based on five-point Likert-type and semantic differential scales were adopted from previous studies to measure CSR, PSQ, trust, repurchase and WOM intentions (Table 1). CSR perceptions were measured following the proposals of Carroll (1979), Maignan 
and Ferrell (2000), Maignan (2001), García de los Salmones et al. (2005) and Mandhachitara and Poolthong (2011). Thus a three-dimensional scale was adapted from these studies to evaluate customer perceptions of the ethical, legal and philanthropic responsibilities of banking companies (Aupperle et al., 1985). Three items measured the ethical dimension (Maignan and Ferrell, 2000; Mandhachitara and Poolthong, 2011), two items were adopted for the legal dimension (Maignan, 2001; García de los Salmones et al., 2005) and four items were included in the philanthropic dimension (García de los Salmones et al., 2005). PSQ was measured by means of a fifteen-item SERVPERF scale adapted from Karatepe et al. (2005). This scale has been especially developed for the banking industry due to its unique nature and different characteristics to other industries. The authors also follow the four-dimensional proposal of Karatepe et al. (2005), who classify their PSQ items into one of the following categories: (1) interaction quality, (2) empathy, (3) reliability and (4) service environment perceptions. The detail of the items used for CSR and PSQ constructs is provided in table 1.

A four-item measurement scale was taken from Sirdeshmukh et al. (2002) to measure customer trust. Respondents were asked to respond on a five-point semantic differential scale. The four items were as follows: (1) very undependable-very dependable (2) very incompetent-very competent (3) of very low integrity-of very high integrity (4) very unresponsive-very responsive.

Finally, the authors measured repurchase and WOM intentions by adopting the loyalty battery developed by Zeithaml et al. (1996). Two-item scale evaluated customers repurchase intentions. The two items were as follows: (1) I shall continue considering this one as my main bank in the next few years (2) I would keep being a customer of this bank even if another entity offered better rates. Three-item scale measured WOM intentions. These items included: (1) I could say positive things about this bank (2) I would recommend this bank if somebody asked my advice (3) I would encourage friends and relatives to contract some product or service from this bank.

\subsection{Assessment of common method variance}

As our study was based on a single type of informant (i.e., customers only) who scored both the dependent and independent variables, the data gathered could be susceptible to common method variance (CMV). Procedural and statistical remedies were used to control for CMV as recommended by Podsakoff et al. (2003). Firstly, almost all the items were adapted and based on previously validated scales. Secondly, all the items were reviewed by experts and pre-tested to avoid vague and unfamiliar terms. Thirdly, some examples of CSR activities were provided, along with CSR items to make them clear, concise and more focused. Fourthly, a proximal separation technique was used for the dependent and independent variables. Different response formats were also used (e.g. a semantic differential scale was employed for trust to break the Likert response format). Fifthly, a block item arrangement was employed rather than a random item arrangement. Sixthly, the CMV caused by contextual cues was addressed as respondents were approached at different bank branches located in different geographical areas of Islamabad and Rawalpindi. Finally, CMV was statistically tested by employing Harman's one-factor test for the whole model. An unrotated principal component factor analysis was performed but the first factor failed to explain the majority of the variance (less than 42 percent of total variance explained). Consequently, CMV was not a concern in this study. 


\section{Findings}

\subsection{Exploratory phase}

During the first stage of the research, the authors tested the multidimensionality theoretically proposed for CSR perceptions and PSQ by means of Principal Components Analyses (PCA). The results of the analyses are reported in Table 1.

Contrary to the three-dimensional perspective defended by previous scholars, CSR perceptions converged into only two dimensions in the present study. The ethical and legal items converged into one factor, subsequently labelled as the CSR ethical-legal dimension. The second factor included four philanthropic items and thus was called the CSR philanthropic dimension. This CSR perceptions construct accounted for 56 percent of the total variance, which is higher than the minimum recommended value of 50\% (Merenda, 1997). All of the item loadings in these two factors exceeded the minimum recommended value of 0.30 (Hair et al., 2010). All the items also exceeded or were very close to the minimum threshold 'practically significant' level of 0.50 (Hair et al., 2010).

\section{Insert Table 1 here}

The PCA analysis for PSQ yielded four dimensions that were consistent with the proposal of Karatepe et al. (2005). Thus, the items were classified into the following factors: (1) interaction quality, (2) empathy, (3) reliability and (4) service environment. Nonetheless, two items of the service environment dimension were eliminated due to high cross loadings. The PCA results demonstrated that the four dimensions explained 56 percent of the variance of the PSQ construct.

\subsection{Confirmatory phase: Construct reliability and validity}

Partial Least Squares-Structural Equation Modelling (PLS-SEM) has been applied to perform Confirmatory Factor Analysis (CFA) and hypothesis testing. PLS-SEM has gained increased attention in customer behaviour marketing studies. By analysing over two hundred articles that have applied PLS-SEM and published in leading marketing journals, Hair et al. (2012) reveal that PLS-SEM is a robust technique that does not require the condition of data normality. They further divulge that marketing scholars apply PLS-SEM due to non-normality of data, small sample sizes and presence of formative constructs in their respective models. PLS-SEM applied in this research due to the concern of data normality. The authors perform screening of the data and evaluate the data normality through skewness, kurtosis, normal probability plots, q-q plots and Kolmogorov-Smirnov test as recommended by Hair et al. (2010). (results of this screening are not provided for the sake of space). Through this screening, it became clear that the data deviate from a normal distribution curve and therefore PLS-SEM has been considered appropriate for this research. PLS-SEM has many distinctive advantages over Covariance Based Structural Equation Modelling (CB-SEM). While it attains high levels of statistical power even with small sample, it also produces similarly reliable results to CB-SEM in large datasets (Hair et al., 2011). A minimum sample size can be calculated by multiplying ten with the largest number of structural paths directed towards an endogenous construct and this can be sufficient for PLSSEM analyses to be robust (Hair et al., 2011). Nonetheless, for this study a relatively larger sample (408 cases) was used to capture more variance within the data analysis. SmartPLS version 2.0.M3 was used for path modelling and data analysis (Ringle et al., 2005). 


\section{Insert Table 2 here}

\section{Insert Table 3 here}

A Confirmatory Factor Analysis (CFA) was performed to assess the quality of the overall model. The results of this analysis are reported in Table 2. One item of the interaction quality dimension (IQ-5) was eliminated due to its unacceptable item loading (0.39) (Hulland, 1999). Moreover, the two-item dimension of service environment failed to load with an acceptable value in the PSQ construct (0.42). Thus, it was also eliminated from the analysis. The item loadings of the rest of items ranged from 0.67 to 0.92 (except RI-2=0.47), which is quite acceptable (Hulland, 1999). The item RI-2 was retained as several scholars argue that the rule of thumb should not be rigid and items with loadings of around 0.5 may still be retained as long as the overall reliability and validity of the construct still satisfies threshold values (Barclay et al., 1995). Construct reliability can be achieved if the Composite Reliability (CR) for each construct is greater than the minimum recommended value of 0.60 (Bagozzi and $\mathrm{Yi}, 1988$ ). In terms of convergent validity, the Average Variance Extracted (AVE) should be greater than 0.50 for each construct (Bagozzi and $\mathrm{Yi}, 1988)$. All the CR and AVE values for each first- and second-order construct exceeded the minimum threshold values, as shown in Table 2. Finally, the discriminant validity of all the five latent factors was assessed through the process proposed by Fornell and Larcker (1981). According to these authors, in order to confirm the discriminant validity of the model it is necessary that the square root of each AVE be greater than the highest correlation between that construct and any other variable in the model. Table 3 shows how the discriminant validity is achieved in the model presented in this paper.

\subsection{Hypotheses testing}

Prior to testing the relationships between variables, a global evaluation of the structural model is required (Hair et al., 2011). The coefficient of determination $\left(\mathrm{R}^{2}\right)$, the Average Variance Accounted For (AVA) and the significance of path coefficients $(\beta)$ are indices that assure the predictive relevance of structural models (Fornell and Cha, 1994). The AVA is calculated as the mean of the $\mathrm{R}^{2}$ of all the endogenous constructs. In this study, the AVA value was 0.29 and all the individual $\mathrm{R}^{2}$ exceeded the threshold value of 0.10 . Thus, the predictive relevance of the model was confirmed (Falk and Miller, 1992). However, a higher value of $\mathrm{R}^{2}$ should be achieved and it depends on field of research. The value of $\mathrm{R}^{2}$ in customer behaviour studies is considered to be high if greater than 0.20 (Hair et al., 2011). The value of $\mathrm{R}^{2}$ for most of the endogenous constructs was higher than 0.20 (see table 4) and therefore, explanatory power of the model was justified.

PLS-SEM requires bootstrapping approach and due to this reason, 5000 samples with 408 cases were used to test the hypothesised relationships as recommended by Hair et al. (2011). The results of the hypotheses testing with their respective t- and p-values are shown in Table 4. Hair et al. (2010) revealed that a hypothesis should be accepted at $1 \%$ level of significance if its tvalue is greater than 2.58 and p-value less than 0.01 . It is clear that there was a direct and positive relationship between CSR perceptions and PSQ $(\beta=0.39$, t-value=8.93). Thus, improvements in customer CSR perceptions caused improvements in PSQ. This finding supports the hypothesis H1. CSR perceptions also directly and positively influenced trust $(\beta=0.25$, $t$ - 
value $=5.10$ ), which demonstrates that an improvement in CSR perceptions generated more trust in customers' minds. Thus, the hypothesis $\mathrm{H} 2$ was also supported. CSR perceptions were also found to have a direct and positive effect on loyalty intentions such as repurchase $(\beta=0.21$, $t$ value=3.69) and WOM $(\beta=0.21, \mathrm{t}$-value=4.78). These findings support the hypotheses $\mathrm{H} 3 \mathrm{a}$ and $\mathrm{H} 3 \mathrm{~b}$.

\section{Insert Table 4 here}

Moreover, PSQ was found to have a positive and direct link with trust $(\beta=0.40, t$-value $=6.41)$. Thus, the hypothesis $\mathrm{H} 4$ is supported. Trust was also positively and directly related to repurchase $(\beta=0.32$, $t$-value $=4.57)$ and WOM intentions $(\beta=0.21, t$-value $=4.06)$. These findings support the hypotheses $\mathrm{H} 5 \mathrm{a}$ and $\mathrm{H} 5 \mathrm{~b}$, respectively. However, the PSQ direct effects on repurchase $(\beta=0.16$, $\mathrm{t}$-value $=2.23)$ and WOM intentions $(\beta=0.10, \mathrm{t}$-value=2.23) were found to be insignificant and therefore the hypotheses $\mathrm{H} 6 \mathrm{a}$ and $\mathrm{H} 6 \mathrm{~b}$ were not supported. These findings indicate the importance of trust as a mediating variable between PSQ and loyalty intentions. However, the authors of research confirm its mediating role by applying mediation test in the next paragraph. Finally, repurchase intentions had a direct and positive impact on WOM intentions $(\beta=0.29$, $t$ value $=5.49$ ). Thus, the hypothesis $\mathrm{H} 7$ was supported.

\subsection{Mediation test for customer trust}

The mediating role of trust between PSQ and loyalty intentions was evaluated by a mediation test suggested by Baron and Kenny (1986). These authors described three conditions in order to decide mediation of a variable. In this regard, the first two conditions include that there must be significant relationships of a proposed mediating variable with independent (IV) and dependent variables (DV). Lastly, it must be checked whether a direct relationship between IV and DV becomes insignificant or weaker in the presence of a mediating variable as compared to its absence in a given model. Full and partial mediation is concluded, in the former and latter cases, respectively. According to these rules, it is clear that within this study, trust has significant relationships with PSQ (IV) and repurchase and WOM intentions (DV's) whereas the direct relationships between IV and DV's such as PSQ-repurchase intentions and PSQ-WOM intentions are insignificant. The results of $\mathrm{H} 4, \mathrm{H} 5 \mathrm{a}, \mathrm{H} 5 \mathrm{~b}, \mathrm{H} 6 \mathrm{a}$ and $\mathrm{H} 6 \mathrm{~b}$ are provided in the table 4. The authors run the model without trust to confirm that whether trust is the reason of insignificance of the direct relationships between the IV and DV's. The results of the direct relationships now found to be significant at $1 \%$ level of significance, i.e. PSQ-repurchase intentions $(\beta=0.28, \mathrm{t}$-value $=3.76, \mathrm{p}$-value $=0.00)$ and PSQ-WOM intentions $(\beta=0.17$, $\mathrm{t}$ value $=3.74, p$-value $=0.00$ ). These results confirm that trust is the full mediating variable because in its presence, the direct relationships of PSQ-repurchase intentions and PSQ-WOM intentions actually become insignificant. Hence, it is concluded that trust serves an important mediating variable between PSQ and loyalty intentions.

\section{Discussion}

This research provides meaningful insights to the literature of services marketing. The outcomes of this research expand the corpus by identifying the effect of CSR perceptions on the PSQloyalty relationships as well as evaluating the mediating role of trust in the banking industry of a 
developing economy. The contributions of this study are presented below with respect to its objectives.

In response to the first objective of this research, the role of CSR perceptions on customer attitudes namely PSQ, trust, repurchase and WOM intentions has been evaluated by extending the García de los Salmones et al.'s (2005) model of CSR-PSQ-loyalty in two directions. First, an important and relevant variable of customer trust has been added into the model that has not been focused in previous literature evaluating the effects of CSR perceptions on the PSQ-loyalty relationship (García de los Salmones et al., 2005; He and Li, 2011; Arıkan and Güner, 2013). Second, the construct of loyalty has been studied with respect to repurchase and WOM intentions. The present study has verified the significant direct impact of CSR perceptions on PSQ, trust, repurchase and WOM intentions. This research appears to be an integrated study that empirically confirms the existence of such direct impacts of CSR on customer attitudes in the banking industry of a developing economy. Earlier studies have reported inconsistent results in this line of research (García de los Salmones et al., 2005; Walsh and Bartikowski, 2013). Nonetheless, with respect to CSR-loyalty intentions, this paper could be considered to be one of the pioneering study as it seeks to provide empirical evidence towards a direct and positive effect from CSR perceptions on customer repurchase and WOM intentions. Along this line, the research confirms the recently reported findings by scholars such as Arıkan and Güner (2013) and Walsh and Bartikowski (2013). Nonetheless, these papers have been developed in the context of western countries. For example, Walsh and Bartikowski (2013) report a positive effect of CSR perceptions on customer loyalty intentions in the context of German grocery customers. On the basis of a customer sample taken from only one Turkish bank, Arıkan and Güner (2013) report similar findings. Therefore, the results reported in the present paper extend previous findings by confirming that customers in a developing economy respond to CSR perceptions similarly to customers in most of the developed countries. With respect to CSR-trust link, it is clear that CSR perceptions boost customer trust. This result is consistent with studies either that conducted in the context of tangible product industries such as cosmetics and sportswear (Swaen and Chumpitaz, 2008) or that employed the context of scenario based cause related marketing (Vlachos et al., 2009). On the other side, previous scholars that have conducted their studies in real service contexts through field surveys, report this result with respect to ethical CSR (García de los Salmones et al. 2009), ethical-legal CSR (Choi and La, 2013). Therefore, the outcomes of present research again provide an integrated view by confirming the impact of a broad spectrum of CSR perceptions (i.e. ethical-legal and philanthropic dimensions) on customer trust in the context of real customers of a retail banking industry.

Additionally, defining CSR perceptions and PSQ as multidimensional constructs provides the leverage to understand underlying patterns within the integrated path model proposed in this research. Regarding CSR perceptions, the findings demonstrate that customers fail to discriminate between ethical and legal responsibilities in the banking industry. Thus, CSR perception is a two-dimensional construct by which Pakistani customers differentiate between legal-ethical and philanthropic responsibilities. This structure is in accordance with the previous findings of García de los Salmones et al. (2005) for customers in the Spanish telecommunication industry. Thus, this finding suggests that service customers in developed and developing economies have similar mental patterns in understanding CSR and so companies should take this consideration into account when designing their international CSR strategies. In fact, the results that concern the PSQ construct demonstrate that Pakistani customers perceive service quality 
differently from customers in other economies. For example, in this research the service environment dimension failed to converge with the PSQ construct. This result is inconsistent with previous findings in academic literature (Karatepe et al., 2005). Thus, the findings suggest that within the scope of this research Pakistani banking customers give least importance to the physical structure of bank branches (factor loading of service environment dimension on PSQ construct was 0.42 only) as compared to customers in other countries. Pakistani customers are more concerned about service characteristics such as technical issues (e.g., reliability) or behavioural attributes (e.g., empathy and interaction quality). Again, this is an interesting finding to be considered by those companies that aim to internationalize their activities in this Asian economy.

With respect to the second objective of the research, mediating role of trust has been evaluated between PSQ and loyalty intentions. The findings have revealed that PSQ does not play the same role in the generation of customer loyalty intentions in the Pakistani and other international banking industries. While previous scholars have reported a direct link between PSQ, repurchase and word of mouth intentions in European markets (Bloemer et al., 1999; Cronin and Taylor, 1992; Zeithaml et al., 1996), in this paper it is shown that PSQ does not directly influence loyalty intentions. On the contrary, the positive effects of PSQ are actually fully mediated by customer trust. This result is also inconsistent with studies that mostly report only a partial mediating effect of trust between such constructs (Chiou and Droge, 2006; Lewis and Soureli, 2006). On the other side, there are limited studies such as Qureshi et al. (2009) that have reported full mediation of this variable between the constructs of perceived reputation and repurchase intentions in the context of online banking. However, within this study, this full mediating role of trust can be described in three possible ways. The first reason derives from the geographical context in which this research was implemented. As suggested by the results of the CFA implemented in this research, Pakistani customers do not process PSQ in the same way as customers in western countries (i.e., there is one dimension of the traditional PSQ construct that failed to converge in the global construct). Thus, it seems that the mental patterns of Pakistani customers regarding PSQ are mainly dependent on interaction quality, empathy and reliability concerns and this fact might determine the role of PSQ in the generation of repurchase and WOM intentions. Secondly, previous papers have evaluated the PSQ-loyalty link in the context of positive phases of the economic cycle (Zeithaml et al., 1996; Bloemer et al., 1999; Lewis and Soureli, 2006). Thus, there is a possibility that the latest economic recession that occurred internationally has conditioned the consequences of PSQ in terms of customer loyalty, which now seems to depend strongly on customer trust in his/her banking company. The possibility also exists that full mediation of this variable might again turn into a partial mediation when economic boom starts. For this purpose, future research will be needed to confirm the behaviour of this variable. Thirdly, as suggested by the previous scholars, corporate scandals and unethical behaviours during a customer-bank relationship increase a customer's scepticism about the trustworthiness of his/her bank (Sureshchandar et al., 2001; 2002; García de los Salmones et al., 2009). Thus, this might indicate that customers have become more sensitive about these unethical behaviours and their trust might have emerged as such a crucial variable that plays a full mediating role between PSQ and loyalty intentions.

\section{Conclusions, limitations and future lines of research}


This study has aimed to examine whether it is useful to integrate customer CSR perceptions and trust in a classic model that explores the relationship between PSQ and loyalty intentions in the context of the banking industry of an emerging market economy.

The study has demonstrated that CSR perceptions play a very important role in the generation of loyalty intentions because not only do they increase the perceptions of service quality and trust, but they also have a direct impact on customer repurchase and WOM intentions. Thus, the findings of the paper suggest that opportunities are also available for companies in the non-core service side of the retail banking industry. In this regard, CSR can serve companies in capturing untapped customer loyalty at the same time as improving PSQ and trust. This finding is one of the most important contributions of the present paper. The authors suggest that, in order to achieve high levels of customer CSR awareness, effective communication through strategic marketing tools is the key to success. For this purpose, a specific marketing plan for CSR activities can be developed and executed through online communication and materials such as pamphlets and brochures. However, the authors also argue that the nature of CSR activities can vary from country to country and even from region to region. Thus, it is the responsibility of corporate managers to effectively identify, properly plan, efficiently execute and professionally market CSR activities to serve as a function of strategic investment rather than an useless expenditure of a firm.

On the contrary, this study suggests that Pakistani customers process PSQ quite differently to customers in other economies. Pakistani customers are more concerned about service characteristics such as the reliability of the company, the empathy of its employees and the quality of the interaction between employees and customers. Therefore, future investments should dominantly be directed towards improvements in banking systems and employee training. Specifically, this paper demonstrates that it is essential to companies operating in Pakistan to establish customer trust in order for their service quality to create more beneficial loyal relationships for them. Thus, in order to maintain a loyal base of customers, this paper verifies that the PSQ-loyalty link no longer exists without the inclusion of customer trust. Again, this is another significant contribution of the present study that signals an important implication to this banking industry. Therefore, banks should not ignore customer trust in order to sustain and further expand the loyal base of their customers. Banks should design their service operations and marketing plans in such manner that revolve around customer trust and CSR. They should make customers feel that they are highly credible, reputable and dependable in their business conducts.

Nonetheless, this study has some limitations that will need to be addressed in future research on this topic. Firstly, the study is based on a single industry and a non-random sample. Therefore, the generalisability of the findings of the paper is limited. Future scholars could address this issue by using larger random samples collected in different industrial contexts. Also, even though the research has been developed in the context of a developing country, the justifications provided for the findings of the study are tentative and should be tested further by using control groups from different countries, types of banking institutions (e.g., micro-finance banks or savings banks) or even companies in different phases of their economic cycles. Finally, the explanatory power of the model could be further increased by including other important variables in the research design (e.g., perceived value, perceived risk and/or switching behaviour). These constructs could also contribute to a better understanding of the complex 
relationships that exist within customers' PSQ, trust, repurchase and WOM behaviours with respect to their CSR perceptions.

\section{References}

Arıkan, E. and Güner, S. (2013), "The impact of corporate social responsibility, service quality and customer-company identification on customers", Procedia-Social and Behavioural Sciences, Vol. 99, pp. 304-313.

Aupperle, K.E., Carroll, A.B. and Hatfield, J.D. (1985), "An empirical examination of the relationship between corporate social responsibility and profitability", Academy of Management Journal, Vol. 28 No. 2, pp. 446-463.

Bagozzi, R.P. and Yi, Y. (1988), "On the evaluation of structural equation models", Journal of the Academy of Marketing Science, Vol. 16 No. 1, pp. 74-94.

Barclay, D., Higgins, C. and Thompson, R. (1995), "The partial least squares (PLS) approach to causal modelling: Personal computer adoption and use as an illustration", Technology Studies, Vol. 2 No. 2, pp. 285-309.

Becker-Olsen, K.L., Cudmore, B.A. and Hill, R.P. (2006), "The impact of perceived corporate social responsibility on consumer behavior", Journal of Business Research, Vol. 59 No. 1, pp. 46-53.

Berens, G., van Riel, C.B. and van Rekom, J. (2007), "The CSR-quality trade-off: when can corporate social responsibility and corporate ability compensate each other? ", Journal of Business Ethics, Vol. 74 No. 3, pp. 233-252.

Bloemer, J., Ruyter, K.D. and Wetzels, M. (1999), "Linking perceived service quality and service loyalty: a multi-dimensional perspective", European Journal of Marketing, Vol. 33 No. 11/12, pp. 1082-1106.

Brown, T.J. and Dacin, P.A. (1997), "The company and the product: Corporate associations and consumer product responses", Journal of Marketing, Vol. 61 No. 1, pp. 68-84.

Carroll, A.B. (1979), "A three-dimensional conceptual model of corporate performance", Academy of Management Review, Vol. 4 No. 4, pp. 497-505.

Chiou, J.S. and Droge, C. (2006), "Service quality, trust, specific asset investment, and expertise: direct and indirect effects in a satisfaction-loyalty framework", Journal of the Academy of Marketing Science, Vol. 34 No. 4, pp. 613-627.

Choi, B. and La, S. (2013), "The impact of corporate social responsibility (CSR) and customer trust on the restoration of loyalty after service failure and recovery", Journal of Services Marketing, Vol. 27 No. 3, pp. 223-233.

Chomvilailuk, K. and Butcher, K. (2013) "The effect of CSR knowledge on customer liking, across cultures”, International Journal of Bank Marketing, Vol. 31 Iss: 2, pp.98-114. 
Cronin, J.J. and Taylor, S.A. (1992), "Measuring service quality: a re-examination and extension", Journal of Marketing, Vol. 56, pp. 55-68.

Dick, A.S. and Basu, K. (1994), "Customer loyalty: towards an integrated conceptual framework", Journal of the Academy of Marketing Science, Vol. 22 No. 2, pp. 99-113.

Eberle, D., Berens, G. and Li, T. (2013), "The impact of interactive corporate social responsibility communication on corporate reputation", Journal of Business Ethics, Vol. 118 No. 4, pp. 731-746.

Falk, R.F. and Miller, N.B. (1992), A Primer for Soft Modelling, University of Akron Press, Akron, $\mathrm{OH}$.

Fornell, C. and Cha, J. (1994), "Partial least squares", in Advanced Methods of Marketing Research, Basil Blackwell, Oxford and Cambridge, MA.

Fornell, C. and Larcker, D.F. (1981), "Evaluating structural equation models with unobservable variables and measurement error", Journal of Marketing Research, Vol. 18, pp. 39-50.

Freeman, R.E. (1984), Strategic Management: A Stakeholder Approach, Pittman, Boston, MA.

García de los Salmones, M.M., Herrero, Á. and Rodríguez del Bosque, I. (2005), "Influence of corporate social responsibility on loyalty and valuation of services", Journal of Business Ethics Vol. 61 No. 4, pp. 369-385.

García de los Salmones, M.M., Pérez, A. and Rodríguez del Bosque, I. (2009), "The social role of financial companies as determinants of consumer behavior", International Journal of Bank Marketing, Vol. 27 No. 6, pp. 467-485.

Hair, J. F. Jr, Black, W. C., Babin, B. J. and Anderson, R. E. (2010). Multivariate Data Analysis, 7th ed., Prentice Hall, Upper Saddle River, NJ.

Hair, J. F., Ringle, C.M. and Sarstedt, M. (2011), "PLS-SEM: indeed a silver bullet", The Journal of Marketing Theory and Practice, Vol. 19 No. 2, pp. 139-152.

Hair, J. F., Sarstedt, M., Ringle, C. M., \& Mena, J. A. (2012). "An assessment of the use of partial least squares structural equation modeling in marketing research" Journal of the Academy of Marketing Science, Vol. 40 No. 3, pp. 414-433.

He, H. and Li, Y. (2011), "CSR and service brand: the mediating effect of brand identification and moderating effect of service quality", Journal of Business Ethics, Vol. 100 No. 4, pp. 673688.

Hulland, J. (1999), "Use of partial least squares (PLS) in strategic management research: a review of four recent studies", Strategic Management Journal, Vol. 20 No. 2, pp. 195-204.

Kantsperger, R. and Kunz, W.H. (2010), "Consumer trust in service companies: a multiple mediating analysis”, Managing Service Quality, Vol. 20 No. 1, pp. 4-25. 
Karatepe, O.M., Yavas, U. and Babakus, E. (2005), "Measuring service quality of banks: Scale development and validation", Journal of Retailing and Consumer Services, Vol. 12 No. 5, pp. 373-383.

Lee, E.M., Park, S. and Pae, J.H. (2011), "The effect of the perceived corporate fit on loyalty: the mediating roles of the corporate social responsibility perception", Journal of Global Academy of Marketing Science, Vol. 21 No. 1, pp. 32-44.

Lee, E.M., Park, S., Rapert, M.I. and Newman, C.L. (2012), "Does perceived consumer fit matter in corporate social responsibility issues?", Journal of Business Research, Vol. 65 No. 11, pp. 1558-1564.

Lewis, B.R. and Soureli, M. (2006), "The antecedents of consumer loyalty in retail banking”, Journal of Consumer Behaviour, Vol. 5 No. 1, pp. 15-31.

Maignan, I. (2001), “Consumers' perceptions of corporate social responsibilities: a cross-cultural comparison", Journal of Business Ethics, Vol. 30 No. 1, pp. 57-72.

Maignan, I. and Ferrell, O.C (2000), "Measuring corporate citizenship in two countries: the case of the United States and France”, Journal of Business Ethics, Vol. 23 No. 3, pp. 283-297.

Maignan, I. and Ferrell, O.C. (2001), "Corporate citizenship as a marketing instrument concepts, evidence and research directions", European Journal of Marketing, Vol. 35 No. 3/4, pp. 457-484.

Mandhachitara, R. and Poolthong, Y. (2011), "A model of customer loyalty and corporate social responsibility”, Journal of Services Marketing, Vol. 25 No. 2, pp. 122-133.

Matute, J., Bravo, R. and Pina, J.M. (2011), "The influence of corporate social responsibility and price fairness on customer behaviour: evidence from the financial sector", Corporate Social Responsibility and Environmental Management, Vol. 18 No. 6, pp. 317-331.

McDonald, L.M. and Lai, C.H. (2011), "Impact of corporate social responsibility initiatives on Taiwanese banking customers", International Journal of Bank Marketing, Vol. 29 No. 1, pp. 5063.

McDonald, L.M. and Rundle-Thiele, S. (2008), "Corporate social responsibility and bank customer satisfaction: a research agenda", International Journal of Bank Marketing, Vol. 26 No. 3, pp. 170-182.

McWilliams, A. and Siegel, D. (2001), "Corporate social responsibility: a theory of the firm perspective", Academy of Management Review, Vol. 26 No. 1, pp. 117-127.

Merenda, P.F. (1997), "A guide to the proper use of factor analysis in the conduct and reporting of research: pitfalls to avoid", Measurement and Evaluation in Counselling and Development, Vol. 30, pp. 156-164.

Mohsan, F., Nawaz, M. M., Khan, M. S., Shaukat, Z. and Aslam, N. (2011), "Impact of customer satisfaction on customer loyalty and intentions to switch: evidence from banking sector of Pakistan", International Journal of Business and Social Science, Vol. 2 No. 16, pp. 230-245. 
Morgan, R.M. and Hunt, S.D. (1994), "The commitment-trust theory of relationship marketing", Journal of Marketing, Vol. 58, pp. 20-38.

Nadiri, H., Hussain, K., Ekiz, E.H. and Erdogan, S. (2008), "An investigation on the factors influencing passengers' loyalty in the North Cyprus national airline", Total Quality Management, Vol. 20 No. 3, pp. 265-280.

Parasuraman, A., Zeithaml, V.A. and Berry, L.L. (1988), "SERVQUAL: A multiple-item scale for measuring consumer perceptions of service quality", Journal of Retailing, Vol. 64 No. 1, pp. $12-40$.

Pérez, A., García de los Salmones, M.M. and Rodríguez del Bosque, I. (2013a), "The effect of corporate associations on consumer behavior", European Journal of Marketing, Vol. 47 No. 1, pp. 218-238.

Pérez, A., Martínez, R.P. and Rodríguez del Bosque, I. (2013b), "The development of a stakeholder-based scale for measuring corporate social responsibility in the banking industry", Service Business, Vol. 7 No. 3, pp. 459-481.

Pirsch, J., Gupta, S. and Grau, S.L. (2007), "A framework for understanding programs as a continuum: An exploratory study", Journal of Business Ethics, Vol. 70 No. 2, pp. 125-140.

Podsakoff, P.M., MacKenzie, S.B., Lee, J.Y. and Podsakoff, N.P. (2003), "Common method biases in behavioural research: a critical review of the literature and recommended remedies", Journal of Applied Psychology, Vol. 88 No. 5, pp. 879-903.

Poolthong, Y. and Mandhachitara, R. (2009), "Customer expectations of CSR, perceived service quality and brand effect in Thai retail banking", International Journal of Bank Marketing, Vol. 27 No. 6, pp. 408-427.

Porter, M.E. and Kramer, M.R. (2006), "The link between competitive advantage and corporate social responsibility", Harvard Business Review, Vol. 84 No. 12, pp. 78-92.

Qureshi, I., Fang, Y., Ramsey, E., McCole, P., Ibbotson, P. and Compeau, D. (2009), "Understanding online customer repurchasing intention and the mediating role of trust-an empirical investigation in two developed countries", European Journal of Information Systems, Vol. 18 No. 3, pp. 205-222.

Ringle, C.M., Wende, S. and Will, A. (2005), SmartPLS (Version 2.0 M3 Beta), available online, URL: www.smartpls.de (accessed 30 July 2013).

SBP (2013), "Statistics on scheduled banks in Pakistan" available online URL: www.sbp.org.pk/publications/schedule_banks/Dec-2013/Title-Review.pdf (accessed 30 January 2014).

Schwartz, M.S. and Carroll, A.B. (2003), "Corporate social responsibility: a three-domain approach", Business Ethics Quarterly, Vol. 13 No. 4, pp. 503-530. 
Sen, S. and Bhattacharya, C.B. (2001), "Does doing good always lead to doing better? Consumer reactions to corporate social responsibility", Journal of Marketing Research, Vol. 38 No. 2, pp. 225-243.

Sirdeshmukh, D., Singh, J. and Sabol, B. (2002), "Consumer trust, value, and loyalty in relational exchanges", Journal of Marketing, Vol. 66, pp. 15-37.

Sureshchandar, G.S., Rajendran, C. and Anantharaman, R. (2002), "Determinants of customerperceived service quality: a confirmatory factor analysis approach", Journal of Services Marketing, Vol. 16 No. 1, pp. 9-34.

Sureshchandar, G.S., Rajendran, C. and Kamalanabhan, T.J. (2001), "Customer perceptions of service quality: a critique", Total Quality Management, Vol. 12 No. 1, pp. 111-124.

Swaen, V. and Chumpitaz, R.C. (2008), "Impact of corporate social responsibility on consumer trust", Recherche et Applications en Marketing (English Edition), Vol. 23 No. 4, pp. 7-34.

Vanniarajan, T. (2011), "Mediator role of customer satisfaction in between after-sales service quality and behavioural intention: the case of electronic appliances", Asia Pacific Business Review, Vol. 7 No. 1, pp. 206-216.

Vlachos, P.A., Tsamakos, A., Vrechopoulos, A. and Avramidis, P. (2009), "Corporate social responsibility: attributions, loyalty and the mediating role of trust", Journal of the Academy of Marketing Science, Vol. 37 No. 2, pp. 170-180.

Walsh, G. and Bartikowski, B. (2013), "Exploring corporate ability and social responsibility associations as antecedents of customer satisfaction cross-culturally", Journal of Business Research, Vol. 66 No. 8, pp. 989-995.

Zeithaml, V.A., Berry, L.L. and Parasuraman, A. (1996), "The behavioural consequences of service quality", Journal of Marketing, Vol. 60, pp. 31-46. 